\title{
Detection of MicroRNAs in Dried Serum Blots
}

Santosh Kumar Patnaik ${ }^{1, a}$, Reema Mallick ${ }^{1,2, a}$ and Sai Yendamuri ${ }^{1,3}$

${ }^{1}$ Department of Thoracic Surgery, Roswell Park Cancer Institute, Buffalo, New York, USA;

${ }^{2}$ Northeastern Ohio Universities College of Medicine, Rootstown, Ohio, USA (present address); ${ }^{3}$ Department of Surgery, State University of New York at Buffalo, Buffalo, New

York, USA

Running title

MicroRNAs in dried serum blots

Address for correspondence

Santosh Kumar Patnaik, MD, PhD

Roswell Park Cancer Institute

Elm and Carlton Streets, CCC C504

Buffalo, NY 14203, USA

Email: santosh.patnaik@yahoo.com

Phone: 1-716-845-8364

Fax: 1-716-845-8922

${ }^{a}$ Joint first authors 


\begin{abstract}
MicroRNAs are short RNAs which can be utilized as biomarkers for a variety of conditions. They are detectable in serum, and changes in the levels of circulating microRNAs have been associated with different diseases. We tested for the presence of microRNAs in serum that is dried on paper and stored unrefrigerated instead of being kept frozen. MicroRNAs were readily detectable in such blots, and their detectability was improved by using paper made of cellulose instead of glass fiber, and by re-hydrating dried blots with Trizol ${ }^{\mathrm{TM}}$ instead of water, phosphate-buffered saline, or guanidine hydrochlodirde before RNA extraction. MicroRNA preservation was not diminished by drying of blots at 37,45 or $60^{\circ} \mathrm{C}$ instead of room temperature or by storage of blots at 37,45 or $60^{\circ} \mathrm{C}$ instead of room temperature, but was worse when blots were dried incompletely or exposed to high humidity during storage. Preservation of microRNAs in serum was not adversely affected if instead of being kept frozen at $-80^{\circ} \mathrm{C}$ it was stored as dried blots at room temperature or $37^{\circ} \mathrm{C}$ for ten or eight and a half months, respectively. In a group of ten individuals, microRNA quantifications of $-80^{\circ} \mathrm{C}-$ frozen or dried sera stored at room temperature correlated well. Dried blots may thus be a convenient and safer way to save, transport, and store serum without refrigeration for microRNA assays.
\end{abstract}

\title{
Keywords
}

blotting, dried serum, exosome, microRNA, RNA preservation, RNA stability, serum storage

\section{Introduction}

MicroRNAs are ultra-short RNA molecules with 19-23 nucleotides that affect the translation of proteins from messenger RNAs to play important roles in normal and pathologic processes. More than 850 microRNAs have been identified in humans as per the miRBase microRNA registry [1]. Changes in expression levels of specific microRNAs in tissues have been associated with a variety of diseases such as cancer [2] and diabetes [3], and physiological conditions such as pregnancy [4] and muscle hypertrophy [5]. Recent studies have shown the presence of microRNAs in human serum and plasma [6; 7]. This finding has the potential to enhance the utility of microRNAs as biomarkers to diagnose, prognosticate, and monitor disease status via non-invasive methods. Indeed, alterations in circulating microRNAs have been observed in cancers such as those of the breast [8], colon [9], lung [10] and prostate [6], as well as during drug-induced hepatic damage [11], myocardial injury [12], pregnancy [7; 13], and sepsis [14].

In vitro experiments using exogenous microRNAs have shown that naked RNA is rapidly degraded by the strong ribonuclease activity present in serum and plasma $[6 ; 15 ; 16]$. It is thus likely that microRNAs released upon cellular lysis do not survive in the circulation. Instead, microRNAs detected in the plasma are likely to be those within membraneenveloped, 50-100 nm-sized secretory microvesicles termed exosomes that are released by cells into the extracellular space and that eventually enter the vascular compartment. Exosomes also contain cellular proteins and messenger RNA transcripts, but lack DNA, nuclear RNA such as small nucleolar RNAs, and ribosomal RNA $[16 ; 17 ; 18]$.

Viral RNAs such as those of HIV-1 [19], hepatitis A [20] and hepatitis C [21] can be detected in dried blood, plasma or serum spots after months of storage outside the refrigerator. MicroRNAs too may be detectable in dried sera and plasma as, akin to viral RNAs, they are protected from ribonucleases by encapsulation and, possibly, from chemical 
hydrolysis by being in the macromolecule-rich interior of the exosome. In this study we tested if microRNAs can be detected in dried serum blots, and examined factors influencing their preservation. Comparisons were made with the detectability and stability of microRNAs in frozen liquid sera.

\section{Materials and Methods}

Human serum samples

This study was approved by an institutional review board at the Roswell Park Cancer Institute. Frozen sera from ten individuals were obtained from the institute's Data Bank and BioRepository. Fresh serum from a healthy, young, male individual was prepared from venous blood collected without any additive using a $22 \mathrm{G}$ needle, clotted at $37^{\circ} \mathrm{C}$ for $30-45$ minutes in a polypropylene tube, and centrifuged twice for ten minutes at $1,500 \mathrm{~g}$ at room temperature $\left(\mathrm{RT}^{\mathrm{b}}\right)$. Frozen sera were kept at $-80^{\circ} \mathrm{C}$ and were not thawed more than three times.

Preparation and storage of dried serum spots

Approximately $0.8 \mathrm{~mm}$-thick GB003 blotting paper made of pure cellulose (Whatman $\AA$, Florham Park, $\mathrm{NJ}$; www.whatman.com) was manually cut into $1 \times 1 \mathrm{~cm}$ square pieces with a sterile steel blade. Forty-five $\mu \mathrm{l}$ of serum was blotted per piece, and the serum spots were dried on a clean, perforated, plastic surface for 1-2 hours under laminar airflow at RT $\left(21^{\circ} \mathrm{C}\right.$ to $24^{\circ} \mathrm{C}$ ) under ambient humidity. Dried serum spots were stored in tightly capped, translucent, $2 \mathrm{ml}$ or $15 \mathrm{ml}$ polypropylene tubes in semi-darkness. Drying or storage at higher temperatures was done in air ovens without any humidity control. For storage under $95 \%$ humidity, a Steri-Cult ${ }^{\mathrm{TM}}$ cell culture incubator (Thermo $®$, Waltham, MA; www.thermo.com) was used. Samples of every sample-type were processed at least in duplicate in each experiment.

\section{Extraction of RNA}

RNA was extracted at the same time in an identical fashion from all samples being examined in an experiment. Four-hundred $\mu \mathrm{l}$ Trizol ${ }^{\mathrm{TM}}$ (Invitrogen ${ }^{\circledR}$, Carlsbad, CA; www.invitrogen.com) was added to a $2 \mathrm{ml}$ tube containing a $1 \times 1 \mathrm{~cm}$ serum blot, and the tube was vortexed at 2000 rotations per minute at $4^{\circ} \mathrm{C}$ for 30 minutes on a Finemixer ${ }^{\mathrm{TM}} \mathrm{SH} 2000$ vortexer (FinePCR $\mathrm{C}$, Seoul, South Korea; www.finepcr.com). In some experiments, the tubes were kept at $-80^{\circ} \mathrm{C}$ for up to a week before processing was resumed. Following further addition of $1.2 \mathrm{ml} \mathrm{Trizol}{ }^{\mathrm{TM}}$ and then $0.24 \mathrm{ml}$ chloroform, the tube was vortexed at RT for five minutes, and after another 2 minutes, centrifuged at $14,000 \mathrm{~g}$ at $4^{\circ} \mathrm{C}$ for 15 minutes. The top, aqueous phase was collected, mixed with an equal volume of ethanol, and processed on PureLink ${ }^{\text {TM }}$ RNA spincolumns (Invitrogen $\AA$ ) on a QIAvac ${ }^{\mathrm{TM}} 24$ Plus apparatus (Qiagen $\AA$, Valencia, CA; www.qiagen.com) as per manufacturers' suggested protocols. RNA was eluted from spincolumns using $100 \mu \mathrm{l}$ water, and stored at $-80^{\circ} \mathrm{C}$. RNA from liquid serum was prepared similarly but with vortexing for only 2 minutes after adding Trizol ${ }^{\mathrm{TM}}$.

${ }^{b} \mathrm{Cl}$, confidence interval; $\mathrm{C}_{\mathrm{q}}$, quantification cycle; RT, room temperature; RT-qPCR, reverse transcription-quantitative polymerase chain reaction 
RNA quantification using Ribogreen dye

Quantlt ${ }^{\mathrm{TM}}$ Ribogreen RNA reagent (Invitrogen ${ }^{\circledR}$ ) was used to quantify nucleic acid in less than 30 day-old RNA preparations in duplicate as per the method suggested by the manufacturer. Briefly, yeast tRNA (Ambion $®$, Austin, TX; www.ambion.com) was used to prepare standards of known concentration. RNA samples were diluted to $100 \mu \mathrm{l}$ using $10 \mathrm{mM}$ tris hydrochloride with $1 \mathrm{mM}$ ethylenediaminetetraacetic acid at $\mathrm{pH} 7.5$, and mixed with $100 \mu \mathrm{l}$ of the same containing 2000x diluted Ribogreen. Fluorescence at $535 \mathrm{~nm}$ following excitation at $485 \mathrm{~nm}$ was measured for $0.1 \mathrm{~s}$ on a Victor Wallac ${ }^{\text {TM }} 1420$ plate reader (Perkin Elmer ${ }^{\circledR}$, Waltham, MA; www.perkinelmer.com).

Semi-quantification of microRNAs by reverse transcription (RT)-quantitative $P C R$ ( $q P C R$ ) Levels of mature microRNAs miR-16, -21 , and -223 were measured in less than ten day-old RNA preparations using TaqMan ${ }^{\mathrm{TM}}$ microRNA assays (Applied Biosystems ${ }^{\circledR}$, Foster City, CA; www.appliedbiosystems.com). RNA preparations from the same time-point and/or experiment were assayed together. TaqMan ${ }^{\mathrm{T}}$ microRNA reverse transcription kit (Applied Biosystems ${ }^{\circledR}$ ) was used for reverse transcribing $9.9 \mu \mathrm{l}$ RNA in $15 \mu \mathrm{l}$ at $42{ }^{\circ} \mathrm{C}$ for 30 minutes using a microRNA-specific oligonucleotide. MicroRNA-specific primers and $1.33 \mu \mathrm{l}$ of RT reactions were used in triplicate 40- or 42-cycle quantitative PCR reactions of $20 \mu$ volume in a $7900 \mathrm{HT}$ thermocycler (Applied Biosystems ${ }^{\circledR}$ ); the denaturation step at $95^{\circ} \mathrm{C}$ was for 15 seconds, and the combined annealing and extension step at $60^{\circ} \mathrm{C}$ was for a minute. Fluorescence from the binding of microRNA-specific, carboxy-fluorescein dye-conjugated probes to amplification products was measured during PCR, and SDS ${ }^{\mathrm{TM}}$ software (version 2.3; Applied Biosystems $\left.{ }^{\circledR}\right)$ was used to identify quantification cycle $\left(\mathrm{C}_{\mathrm{q}}\right)$ values as the average of values from the triplicate PCR reactions. When an experiment was duplicated, all $\mathrm{C}_{\mathrm{q}}$ values obtained in the second experiment were identically adjusted by addition of a constant such that the average $C_{q}$ values for the reference sample-types (frozen serum, or serum blot dried and stored at RT) was the same in the two experiments.

\section{Other}

Statistical analyses and graphical plotting were done using Prism ${ }^{\mathrm{TM}}$ (version 5.0b; GraphPad Software ${ }^{\circledR}$, La Jolla, CA; www.graphpad.com) and Excel ${ }^{\mathrm{TM}}$ software (version 2008 for Mac; Microsoft $\Theta$, Redmond, WA; www.microsoft.com). All t and Mann Whitney $U$ tests were twotailed tests. The $t$ tests assumed equal variances as suggested by $P$ values of $\geq 0.05$ in $F$ tests.

\section{Results}

Detection of microRNAs in dried serum spots

To test preservation of microRNAs in dried serum blots, $45 \mu \mathrm{l}$ fresh serum was spotted per $1 \times 1 \mathrm{~cm}$ piece of $0.8 \mathrm{~mm}$-thick pure cellulose paper (mean weight, $32 \mathrm{mg}$; range, 29-36; standard deviation, $3 ; 2.2 \%$ moisture-content as measured by analytical weighing before and after drying at $60^{\circ} \mathrm{C}$ for three hours) and dried at RT $\left(21^{\circ} \mathrm{C}\right.$ to $\left.24^{\circ} \mathrm{C}\right)$ under laminar air-flow. Weighing of the blots showed that complete drying was achieved within an hour. The dried serum spots were stored at RT in tightly-capped polypropylene tubes for 30 hours before blots were re-hydrated for 30 minutes at $4^{\circ} \mathrm{C}$. RNA was then extracted from the blots using Trizol $^{\mathrm{TM}}$ reagent for semi-quantification of $m i R-16$, a microRNA known to be abundant in 
serum [15], by RT-qPCR. As shown in figure 1, the microRNA could be detected in RNA extracted from the dried blots, whereas no RT-qPCR signal was detected from blank blots that were not spotted with serum (data not shown).

The microRNA yield, as assessed by miR-16 RT-qPCR, was highest when Trizol ${ }^{\mathrm{TM}}$, which inactivates ribonucleases, was used for re-hydration; water, phosphate-buffered saline, water and Trizol ${ }^{\mathrm{TM}}$ together at a 1:1 volumetric ratio, and $6 \mathrm{M}$ guanidine hydrochloride, a chaotropic salt that can inhibit ribonucleases [22], all resulted in reduced yields as indicated by average increases of 1.5, 1.1, 0.4 and 1.3, respectively, in the $C_{q}$ values (figure 1 ). The reduction was statistically significant in t tests in the cases of phosphate-buffered saline, water and guanidine hydrochloride ( $P$ values of $0.0006,0.01$ and 0.0009 , respectively). $P$ values in the non-parametric Mann Whitney $U$ tests were 0.03 in the three comparisons. RNA yield was similar when the duration of the Trizol ${ }^{\mathrm{TM}}$-using re-hydration step was reduced from 30 to five minutes (supplementary figure 1).

\section{Effect of temperature, type of paper, and humidity}

To test the effect of higher temperatures, blotted serum spots were also dried at 37,45 or 60 ${ }^{\circ} \mathrm{C}$ but in the absence of a laminar air-flow. Weight measurements of the blots showed that complete drying was achieved in all cases within an hour. The dried blots were stored at RT for three days. MicroRNA yield from the blots was assessed indirectly by miR-16 RT-qPCR. As shown in figure $2 \mathrm{~A}$, drying at 37 or $45^{\circ} \mathrm{C}$ did not reduce microRNA yield compared to drying at RT ( $P$ values of 0.07 and 0.34 , respectively). Corresponding $U$ test $P$ values were 0.11 and 0.34 , respectively. MicroRNA yield was improved when blots were dried at $60{ }^{\circ} \mathrm{C}$ instead of RT ( $t$ and $U$ test $P$ values of 0.0002 and 0.03 , respectively).

When blots dried at RT were stored at 37,45 or $60^{\circ} \mathrm{C}$ instead of RT for three days, there was an average decrease of $0.9,0.3$ and -0.1 , respectively, in the $C_{q}$ values (figure $2 \mathrm{~A}$ ). Thus, storage at 37,45 or $60^{\circ} \mathrm{C}$ did not reduce the preservation of microRNAs when compared to storage at $R T$ ( $t$ and $U$ test $P$ values of $0.03,0.11$ and 0.79 , and $0.11,0.20$ and 0.89 , respectively).

Unlike on cellulose paper, dried serum spots prepared on glass fiber paper (Whatman® GF/F) by drying at RT, and stored at RT had poorer preservation of microRNAs as indicated by an average decrease of 1.1 in the $C_{q}$ value ( $t$ and $U$ test $P$ values of 0.005 and 0.03 , respectively; figure $2 \mathrm{~B}$ ).

To test the effect of humidity on the stability of microRNAs, blots were dried incompletely at RT without a laminar air-flow, and stored at RT, and compared with blots dried similarly but under laminar air-flow and stored at RT for 30 hours. In the absence of laminar air-flow, drying was less than $50 \%$ complete. Similarly, completely dried blots prepared at RT were stored either air-tight or exposed to $95 \%$ humidity at $37^{\circ} \mathrm{C}$ for 30 hours. As shown in figure $2 \mathrm{C}$, miR-16 RT-qPCR assays suggested that incomplete drying reduced the yield of RNA from the blots, though the average difference in $C_{q}$ value of 1.6 was not considered statistically significant ( $t$ and $U$ test $P$ values of 0.07 and 0.03 , respectively). Also as shown in figure $2 \mathrm{C}$, miR-16 RT-qPCR assays suggested that exposure to $95 \%$ humidity reduced the yield of RNA from the blots, though the average difference in $C_{q}$ values of 0.6 was not found to be statistically significant ( $t$ and $U$ test $P$ values of 0.21 and 0.69 , respectively).

Comparison of microRNA preservation in dried blots with that in frozen sera 
To compare the preservation of microRNAs in dried serum blots to that in liquid serum stored frozen at $-80^{\circ} \mathrm{C}$, blots were prepared at $\mathrm{RT}$ and stored at $-80^{\circ} \mathrm{C}, \mathrm{RT}$ or $37^{\circ} \mathrm{C}$ for $7,14,21$ or 28 days. Concurrently, aliquots of the same serum sample were stored frozen at $-80^{\circ} \mathrm{C}$ for the same durations. RNA yields at the various time-points were assessed by both miR-16 RT-qPCR and Ribogreen dye-based RNA quantification assays. As shown in figure $3 \mathrm{~A}, \mathrm{miR}$ 16 RT-qPCR $C_{q}$ values among the different sample-types were similar for all of the four timepoints. Because the RNA preparations and assays were performed separately at each timepoint, a cross-time-point comparison could not be made. However, comparisons of the average $C_{q}$ value observed for each sample-type at the four time-points along the time-series using paired $t$ tests showed that the performance of blots over time was not different from that of frozen liquid ( $P$ values of $0.65,0.69$ and 0.12 , respectively, for blots stored at $-80^{\circ} \mathrm{C}, \mathrm{RT}$ and $37^{\circ} \mathrm{C}$ ). $\mathrm{P}$ values in the non-parametric Wilcoxon matched-pairs signed rank tests were $0.63,0.63$ and 0.13 , respectively. A similar result was obtained in a separate but identical time-series experiment (supplementary figure 2).

Paired $t$ tests of Ribogreen dye-based nucleic acid measurements of the RNA preparations with time as the variable also suggested that the performance of dried serum blots over time was not different from that of frozen liquid serum (figure 3B). P values were $0.78,0.74$ and 0.11 , respectively, for blots stored at $-80^{\circ} \mathrm{C}, \mathrm{RT}$ and $37^{\circ} \mathrm{C}$. $\mathrm{P}$ values in the non-parametric Wilcoxon matched-pairs signed rank tests were $0.88,0.88$ and 0.25 , respectively. The somewhat higher RNA yield for all sample-types at the 28 day time-point (figure 3B) may be because of the shorter duration for which the RNA preparations from that time-point were stored before the assay. As has been shown, the high variability of measurements among duplicate samples in the Ribogreen assay likely reflect the low analyte concentrations in the RNA preparations [23].

Even after five months of storage, microRNA yield from dried serum blots kept at RT was not reduced compared to that from $-80^{\circ} \mathrm{C}$-frozen liquid serum (figure $3 \mathrm{C}$; $t$ and $\mathrm{U}$ test $\mathrm{P}$ values of 0.10 and 0.06 , respectively). After ten months of storage, in a separate experiment, microRNA yield from dried serum blots kept at RT too was not reduced compared to that from $-80^{\circ} \mathrm{C}$-frozen liquid serum (figure $3 \mathrm{D}$; $t$ and $U$ test $P$ values of 0.41 and 0.66 , respectively). In another experiment, after 8.5 months of storage, microRNA yield from dried serum blots kept at $\mathrm{RT}$ or $37^{\circ} \mathrm{C}$ was not reduced compared to that from $-80^{\circ} \mathrm{C}$-frozen liquid serum (figure $3 \mathrm{E} ; \mathrm{t}$ test $P$ values of 0.05 and 0.01 , respectively). Similar equivalence between frozen and dried sera was also observed when blots were stored at $45^{\circ} \mathrm{C}$ for a week (supplementary figure 3 ).

To rule out an effect of the blot paper on the extractability of RNA, blank blots were added to some tubes of liquid serum immediately before RNA extraction. No significant effect of the cellulose paper-piece on RNA yield was seen (supplementary figure 4).

\section{Correlation in microRNA measurements of liquid and dried sera}

To assess equivalent detectability of inter-individual variations in microRNA levels using frozen and dried sera, dried $45 \mu \mathrm{l}$ serum-spots were prepared in duplicate at RT from sera from ten individuals and stored at RT for 18 days. RNA was then extracted from the blots as well as from $45 \mu \mathrm{l}$ liquid sera stored frozen at $-80^{\circ} \mathrm{C}$, and levels of two microRNAs, miR-21 and miR-223, both known to be present in human serum [15], were quantified by RT-qPCR (figure 4). For miR-21, the Pearson correlation coefficient for the determined $\mathrm{C}_{\mathrm{q}}$ values was 0.82 with $95 \%$ confidence interval $(\mathrm{Cl})$ of $0.39-0.96$ between dried and liquid sera with a $\mathrm{P}$ value of 0.0037 in t test. For miR-223, the coefficient was $0.89(95 \% \mathrm{Cl}=0.60-0.97 ; \mathrm{P}=$ 
0.0005). For comparison, the correlation coefficient for the duplicate sets of dried sera, for miR-223, and of the liquid sera, for $m i R-21$, were $0.83(95 \% \mathrm{Cl}=0.42-0.96 ; \mathrm{P}=0.003)$ and $0.85(95 \% \mathrm{Cl}=0.47-0.96 ; \mathrm{P}=0.002)$, respectively. Thus, a good correlation in microRNA yields from frozen and dried sera was observed.

\section{Discussion}

With microRNAs emerging as biomarkers for diverse diseases, the ability to detect them in dried serum or plasma spots can facilitate the development and use of microRNA-based assays by simplifying sample storage and transportation. Dried serum and plasma spots have been used to assay many different analytes, like ferritin [24], anti-rubella antibodies [25], and cholesterol [26], but the suitability of such blots for analyzing microRNAs is unknown. The stability of RNAs is temperature-sensitive, often requiring storage of RNA or RNAcontaining specimens in a frozen state. Also, the presence of high amounts of ribonucleases in serum seems to suggest that RNAs are unlikely to survive in serum dried and stored at non-freezing temperatures. However, RNAs of viruses such as hepatitis C [21] and HIV-1 [19] in sera of infected individuals have been successfully detected in dried serum or plasma spots stored at RT. Because circulating microRNAs are believed to be encapsulated within membrane-bound exosomes [27], like viral RNAs are within viruses, the possibility of detecting them in dried serum blots was explored in this study.

We found that microRNAs can indeed be detected in dried serum spots prepared on cellulose paper (figures 1-4). Trizol ${ }^{\mathrm{TM}}$ was found to be better than water or buffered saline for re-hydrating the blots for RNA isolation (figure 1). It is possible that exosomes undergo structural damage during desiccation thereby exposing the microRNAs within to ribonucleases during any re-hydration before RNA is extracted, and the effectiveness of Trizol $^{\mathrm{TM}}$ could therefore be because of its ribonuclease-inhibiting activity. Compared to cellulose, glass fiber was not as good a matrix at preserving the RNA in dried serum (figure 2B). Thus, it is possible for the blot matrix to affect exosomal integrity as serum dries on it.

The preservation of microRNAs seems to be as good in dried serum spots as in liquid sera stored frozen at $-80^{\circ} \mathrm{C}$ even after storage of the blots at $45^{\circ} \mathrm{C}$ for a week, at $37^{\circ} \mathrm{C}$ for 8.5 months, or at RT for ten months (figure 3, and supplementary figures 2-3). Further, a high correlation was observed between measurements of specific microRNAs in RNA prepared from liquid and dried serum samples from ten individuals (figure 4). The observation that drying at 37,45 or $60^{\circ} \mathrm{C}$ when compared to RT, or storage for 3 days at 37,45 or $60^{\circ} \mathrm{C}$ when compared to RT, does not reduce RNA yield from the spots (figure $2 \mathrm{~A}$ ) suggests that microRNAs in dried serum spots may remain preserved in spite of the high temperatures that are prevalent in certain geographical regions, or those which the spots may get exposed to during transportation. As has been shown for viral RNAs [28], incomplete drying or exposure to high humidity suggested decreased microRNA preservation in the spots, though, with sample-sizes of four, the decrease was found not to be statistically significant (figure $2 \mathrm{C}$ ). It is of interest that drying or storage at higher temperatures seems to lead to a better preservation of RNA in the blots (figures $2 \mathrm{~A}$ and 3 ). This possibly could be because of the reduced ribonuclease action resulting from a faster evaporation of moisture from the blots. It should be noted that in this study humidity was not specifically controlled, e.g., through the use of desiccants, and it is possible that even better microRNA preservation may be achieved through the use of desiccants to ensure complete dryness during storage. 
Using material like SampleTanker [29], it may be feasible to handle volumes of serum larger than the $45 \mu \mathrm{l}$ used in the experiments in this study for drying and storage for microRNA assays at a later time-point. Dried blots may also be usable for profiling microRNAs in other body fluids such as saliva [30; 31] and urine [32]. Though long-term preservation of microRNAs beyond a few months was not tested in this exploratory study, microRNAs may remain detectable in dried blots for even decades as has been shown for mRNAs in dried blood spots [33]. It is also possible that non-microRNA RNA such as mRNAs that are present in exosomes might be similarly preserved. Because exosomes are generated as vesicles within a cell, microRNAs might also be detectable in dried cellular material. Such findings can have implications for the fields of forensic science and archaeobiology.

This exploratory study shows the feasibility of using dried serum spots for quantification of microRNAs and suggests that blotting and drying as paper spots can be a convenient and less hazardous way to save, transport, and store biological fluids for such purpose. Considering the small sample-sizes in many of the experiments described here, larger studies are needed to identify subtle effects, deleterious or otherwise, of environmental conditions and time on the preservation of the microRNAs in the blots.

\section{Acknowledgements}

We thank Dr. Saroj Patnaik, Army Medical Corps, India for suggesting the question addressed in this study. We also thank Eric Kannisto for assisting with some of the experiments. This work was supported by the National Institutes of Health (grant number R03CA142075-01 to S.K.P.), American Association for Thoracic Surgery (summer intern scholarship to R.M.), and the Roswell Park Cancer Institute and the State University of New York at Buffalo (to S.Y.).

\section{References}

[1] S. Griffiths-Jones, miRBase: the microRNA sequence database. Methods Mol Biol 342 (2006) 129-38.

[2] C.M. Croce, Causes and consequences of microRNA dysregulation in cancer. Nat Rev Genet 10 (2009) 704-14.

[3] A.K. Pandey, P. Agarwal, K. Kaur, and M. Datta, MicroRNAs in diabetes: tiny players in big disease. Cell Physiol Biochem 23 (2009) 221-32.

[4] B.L. Pineles, R. Romero, D. Montenegro, A.L. Tarca, Y.M. Han, Y.M. Kim, S. Draghici, J. Espinoza, J.P. Kusanovic, P. Mittal, S.S. Hassan, and C.J. Kim, Distinct subsets of microRNAs are expressed differentially in the human placentas of patients with preeclampsia. Am J Obstet Gynecol 196 (2007) 261 e1-6.

[5] A. Care, D. Catalucci, F. Felicetti, D. Bonci, A. Addario, P. Gallo, M.L. Bang, P. Segnalini, Y. Gu, N.D. Dalton, L. Elia, M.V. Latronico, M. Hoydal, C. Autore, M.A. Russo, G.W. Dorn, 2nd, O. Ellingsen, P. Ruiz-Lozano, K.L. Peterson, C.M. Croce, C. Peschle, and G. Condorelli, MicroRNA-133 controls cardiac hypertrophy. Nat Med 13 (2007) 613-8.

[6] P.S. Mitchell, R.K. Parkin, E.M. Kroh, B.R. Fritz, S.K. Wyman, E.L. Pogosova-Agadjanyan, A. Peterson, J. Noteboom, K.C. O'Briant, A. Allen, D.W. Lin, N. Urban, C.W. Drescher, B.S. Knudsen, D.L. Stirewalt, R. Gentleman, R.L. Vessella, P.S. Nelson, D.B. Martin, and M. Tewari, Circulating microRNAs as stable blood-based markers for cancer detection. Proc Natl Acad Sci U S A 105 (2008) 10513-8. 
[7] S.S. Chim, T.K. Shing, E.C. Hung, T.Y. Leung, T.K. Lau, R.W. Chiu, and Y.M. Lo, Detection and characterization of placental microRNAs in maternal plasma. Clin Chem 54 (2008) 482-90.

[8] W. Zhu, W. Qin, U. Atasoy, and E.R. Sauter, Circulating microRNAs in breast cancer and healthy subjects. BMC Res Notes 2 (2009) 89.

[9] Z. Huang, D. Huang, S. Ni, Z. Peng, W. Sheng, and X. Du, Plasma microRNAs are promising novel biomarkers for early detection of colorectal cancer. Int J Cancer (2009). [10] G. Rabinowits, C. Gercel-Taylor, J.M. Day, D.D. Taylor, and G.H. Kloecker, Exosomal microRNA: a diagnostic marker for lung cancer. Clin Lung Cancer 10 (2009) 42-6.

[11] K. Wang, S. Zhang, B. Marzolf, P. Troisch, A. Brightman, Z. Hu, L.E. Hood, and D.J. Galas, Circulating microRNAs, potential biomarkers for drug-induced liver injury. Proc Natl Acad Sci U S A 106 (2009) 4402-7.

[12] X. Ji, R. Takahashi, Y. Hiura, G. Hirokawa, Y. Fukushima, and N. Iwai, Plasma miR-208 as a biomarker of myocardial injury. Clin Chem 55 (2009) 1944-9.

[13] S. Gilad, E. Meiri, Y. Yogev, S. Benjamin, D. Lebanony, N. Yerushalmi, H. Benjamin, M. Kushnir, H. Cholakh, N. Melamed, Z. Bentwich, M. Hod, Y. Goren, and A. Chajut, Serum microRNAs are promising novel biomarkers. PLoS One 3 (2008) e3148.

[14] C. Vasilescu, S. Rossi, M. Shimizu, S. Tudor, A. Veronese, M. Ferracin, M.S. Nicoloso, E. Barbarotto, M. Popa, O. Stanciulea, M.H. Fernandez, D. Tulbure, C.E. Bueso-Ramos, M. Negrini, and G.A. Calin, MicroRNA fingerprints identify miR-150 as a plasma prognostic marker in patients with sepsis. PLoS One 4 (2009) e7405.

[15] X. Chen, Y. Ba, L. Ma, X. Cai, Y. Yin, K. Wang, J. Guo, Y. Zhang, J. Chen, X. Guo, Q. Li, X. Li, W. Wang, J. Wang, X. Jiang, Y. Xiang, C. Xu, P. Zheng, J. Zhang, R. Li, H. Zhang, X. Shang, T. Gong, G. Ning, K. Zen, and C.Y. Zhang, Characterization of microRNAs in serum: a novel class of biomarkers for diagnosis of cancer and other diseases. Cell Res 18 (2008) 997-1006.

[16] J. Skog, T. Wurdinger, S. van Rijn, D.H. Meijer, L. Gainche, M. Sena-Esteves, W.T. Curry, Jr., B.S. Carter, A.M. Krichevsky, and X.O. Breakefield, Glioblastoma microvesicles transport RNA and proteins that promote tumour growth and provide diagnostic biomarkers. Nat Cell Biol 10 (2008) 1470-6.

[17] H. Valadi, K. Ekstrom, A. Bossios, M. Sjostrand, J.J. Lee, and J.O. Lotvall, Exosomemediated transfer of mRNAs and microRNAs is a novel mechanism of genetic exchange between cells. Nat Cell Biol 9 (2007) 654-9.

[18] M.J. Lodes, M. Caraballo, D. Suciu, S. Munro, A. Kumar, and B. Anderson, Detection of cancer with serum miRNAs on an oligonucleotide microarray. PLoS One 4 (2009) e6229.

[19] S. Cassol, M.J. Gill, R. Pilon, M. Cormier, R.F. Voigt, B. Willoughby, and J. Forbes, Quantification of human immunodeficiency virus type 1 RNA from dried plasma spots collected on filter paper. J Clin Microbiol 35 (1997) 2795-801.

[20] D. Desbois, A.M. Roque-Afonso, P. Lebraud, and E. Dussaix, Use of dried serum spots for serological and molecular detection of hepatitis a virus. J Clin Microbiol 47 (2009) 153642.

[21] K. Abe, and N. Konomi, Hepatitis C virus RNA in dried serum spotted onto filter paper is stable at room temperature. J Clin Microbiol 36 (1998) 3070-2.

[22] R.J. MacDonald, G.H. Swift, A.E. Przybyla, and J.M. Chirgwin, Isolation of RNA using guanidinium salts. Methods Enzymol 152 (1987) 219-27. 
[23] R.t. Aranda, S.M. Dineen, R.L. Craig, R.A. Guerrieri, and J.M. Robertson, Comparison and evaluation of RNA quantification methods using viral, prokaryotic, and eukaryotic RNA over a 10(4) concentration range. Anal Biochem 387 (2009) 122-7.

[24] C.H. Flowers, and J.D. Cook, Dried plasma spot measurements of ferritin and transferrin receptor for assessing iron status. Clin Chem 45 (1999) 1826-32.

[25] P. Hardelid, D. Williams, C. Dezateux, W.D. Cubitt, C.S. Peckham, P.A. Tookey, and M. Cortina-Borja, Agreement of rubella IgG antibody measured in serum and dried blood spots using two commercial enzyme-linked immunosorbent assays. J Med Virol 80 (2008) 360-4. [26] L. Ramakrishnan, K.S. Reddy, and B.L. Jailkhani, Measurement of cholesterol and triglycerides in dried serum and the effect of storage. Clin Chem 47 (2001) 1113-5.

[27] M.A. Cortez, and G.A. Calin, MicroRNA identification in plasma and serum: a new tool to diagnose and monitor diseases. Expert Opin Biol Ther 9 (2009) 703-711.

[28] J.G. Garcia-Lerma, A. McNulty, C. Jennings, D. Huang, W. Heneine, and J.W. Bremer, Rapid decline in the efficiency of HIV drug resistance genotyping from dried blood spots (DBS) and dried plasma spots (DPS) stored at 37 degrees $\mathrm{C}$ and high humidity. J Antimicrob Chemother 64 (2009) 33-6.

[29] R.M. Lloyd, Jr., D.A. Burns, J.T. Huong, R.L. Mathis, M.A. Winters, M. Tanner, A. De La Rosa, B. Yen-Lieberman, W. Armstrong, A. Taege, D.R. McClernon, J.L. Wetshtein, B.M. Friedrich, M.R. Ferguson, W. O'Brien, P.M. Feorino, and M. Holodniy, Dried-plasma transport using a novel matrix and collection system for human immunodeficiency virus and hepatitis $\mathrm{C}$ virus virologic testing. J Clin Microbiol 47 (2009) 1491-6.

[30] A. Michael, S.D. Bajracharya, P.S. Yuen, H. Zhou, R.A. Star, G.G. Illei, and I. Alevizos, Exosomes from human saliva as a source of microRNA biomarkers. Oral Dis (2009).

[31] N.J. Park, H. Zhou, D. Elashoff, B.S. Henson, D.A. Kastratovic, E. Abemayor, and D.T. Wong, Salivary microRNA: discovery, characterization, and clinical utility for oral cancer detection. Clin Cancer Res 15 (2009) 5473-7.

[32] M. Hanke, K. Hoefig, H. Merz, A.C. Feller, I. Kausch, D. Jocham, J.M. Warnecke, and G. Sczakiel, A robust methodology to study urine microRNA as tumor marker: microRNA-126 and microRNA-182 are related to urinary bladder cancer. Urol Oncol (2009).

[33] H. Karlsson, C. Guthenberg, U. von Dobeln, and K. Kristenssson, Extraction of RNA from dried blood on filter papers after long-term storage. Clin Chem 49 (2003) 979-81.

\section{Figure Legends}

Figure 1

Effect of re-hydrating reagents on the recovery of microRNAs from dried serum blots. MicroRNA miR-16 was semi-quantified in RNA prepared from 30 hour-old dried serum spots prepared and stored at room temperature that were re-hydrated using indicated reagents ( $P B S$, phosphate buffered saline; $\mathrm{GnHCl}, 6 \mathrm{M}$ guanidine hydrochloride). Mean and standard error of mean of RT-qPCR $C_{q}$ values for quadruplicate samples are shown.

\section{Figure 2}

Effect of temperature, type of paper, and humidity on the preservation of microRNAs in dried serum blots. MicroRNA miR-16 was semi-quantified in RNA prepared from $(A)$ three day-old dried serum spots prepared and stored at indicated temperatures (degree Celsius; $R T$, room temperature); $(B) 30$ hour-old dried serum spots prepared on glass fiber or cellulose; and, $(C)$ 30 hour-old dried serum spots dried completely (+) or not (-) at room temperature, and stored 
at room temperature or $37^{\circ} \mathrm{C}$ in presence $(+)$ or absence $(-)$ of an atmosphere of $95 \%$ humidity. Mean and standard error of mean of RT-qPCR $\mathrm{C}_{q}$ values for quadruplicate samples are shown.

\section{Figure 3}

Equivalence of microRNA preservation in frozen and dried serum over time. A. MicroRNA miR-16 was semi-quantified in RNA prepared from serum that was kept frozen at $-80^{\circ} \mathrm{C}$ or dried at room temperature for storage at indicated temperatures for $7,14,21$ or 28 days. Samples from the same time-point were processed for RT-qPCR together but separately from those from other time-points. $B$. RNA yields as suggested by Ribogreen dye-based quantification of RNA in the serum samples. $C$ and $D$. Like $A$, but after storage for five and ten months, respectively, with blots stored at room temperature. $E$. Like $A$, but after storage for 8.5 months. For $D$ and $E$, miR-21 quantifications are shown. Mean and range of RT-qPCR $\mathrm{C}_{\mathrm{q}}$ values $(A, C)$ or RNA yields $(B)$ for duplicate $(A, B$, and the first and third groups in $E)$ or quadruplicate $(C, D$, and the second and fourth groups in $E)$ samples are shown.

Figure 4

Correlation of microRNA measurements in frozen and dried sera. MicroRNAs miR-21 $(A)$ or miR-223 $(B)$ were semi-quantified in RNA prepared from sera from ten individuals that were kept frozen at $-80^{\circ} \mathrm{C}$, or dried and stored for 18 days at room temperature. Mean and range of RT-qPCR $\mathrm{C}_{\mathrm{q}}$ values for duplicate samples, and best-fitting linear regression lines are shown. 
Figure 1

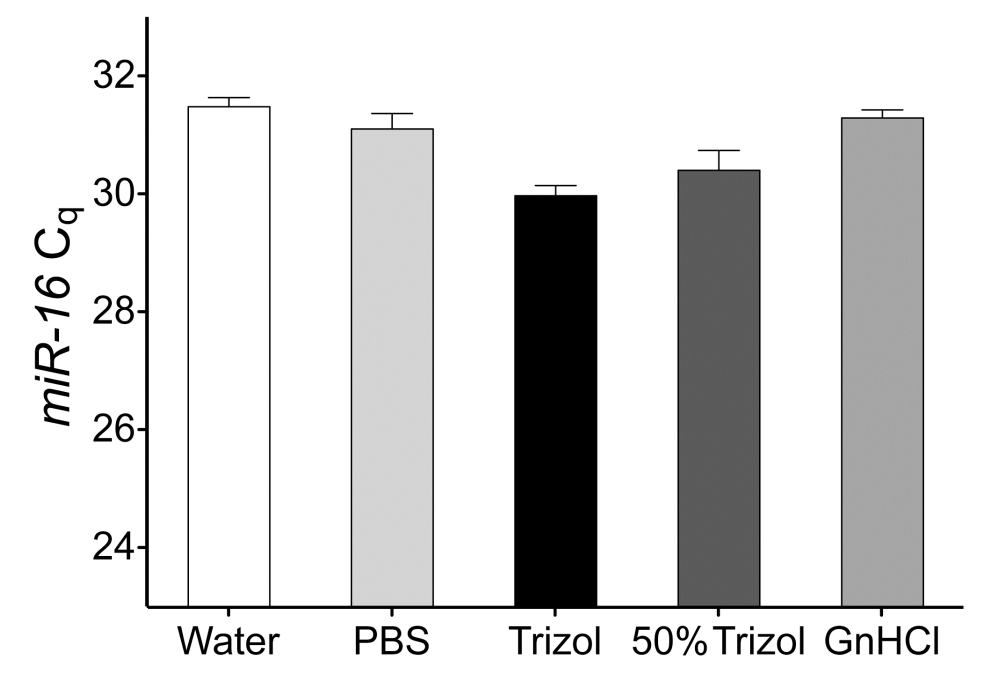


Figure 2
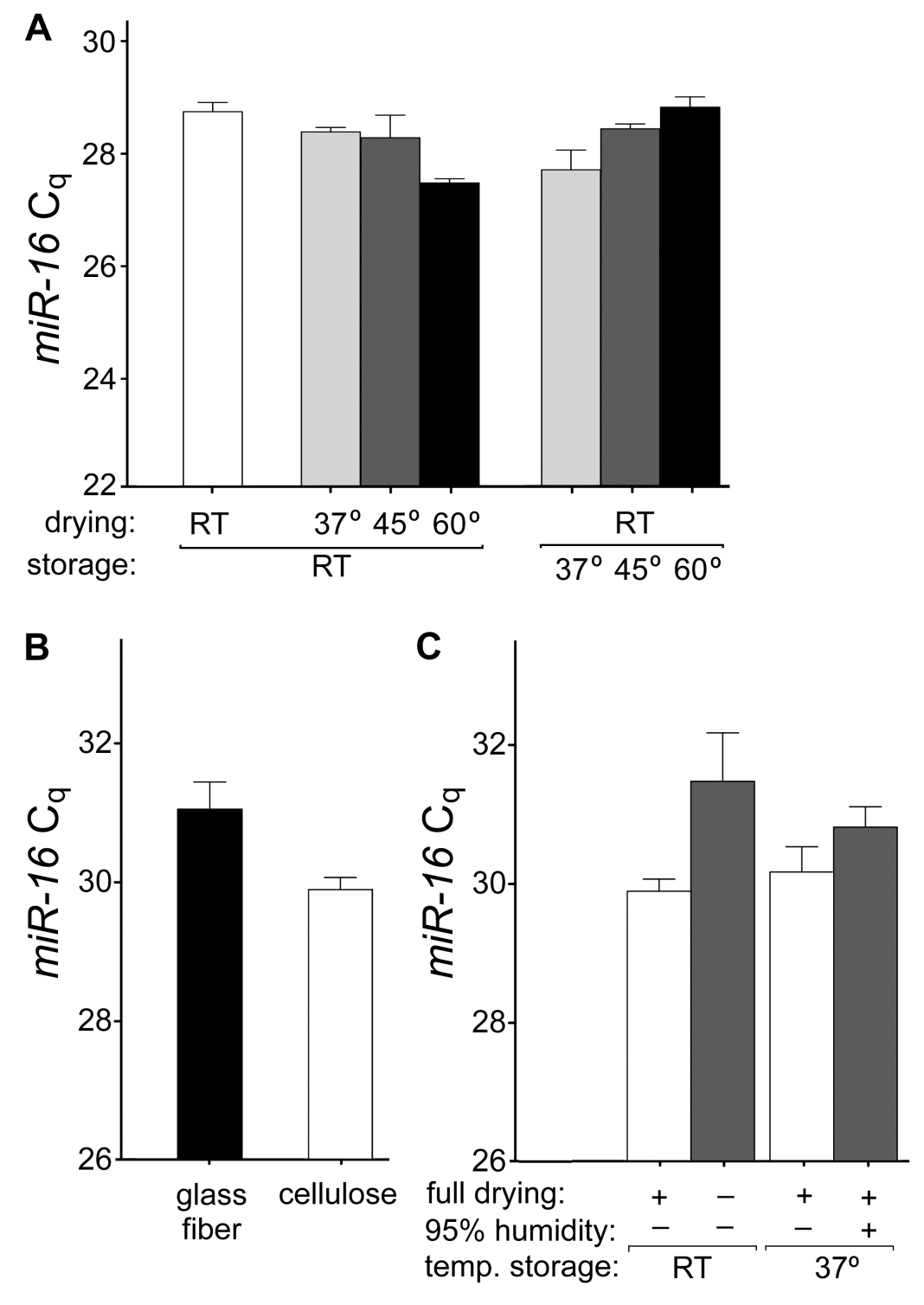
Figure 3

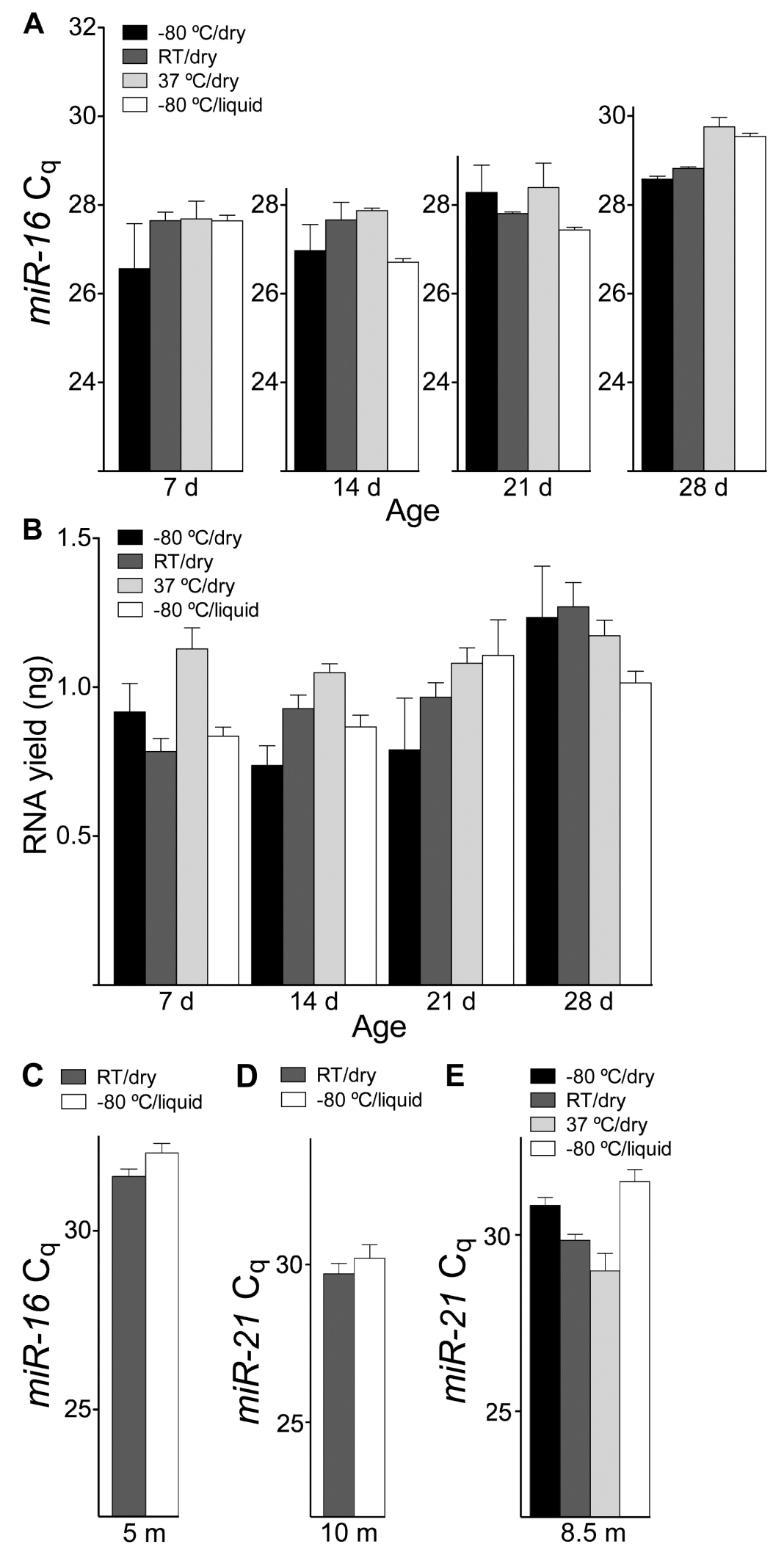


Figure 4
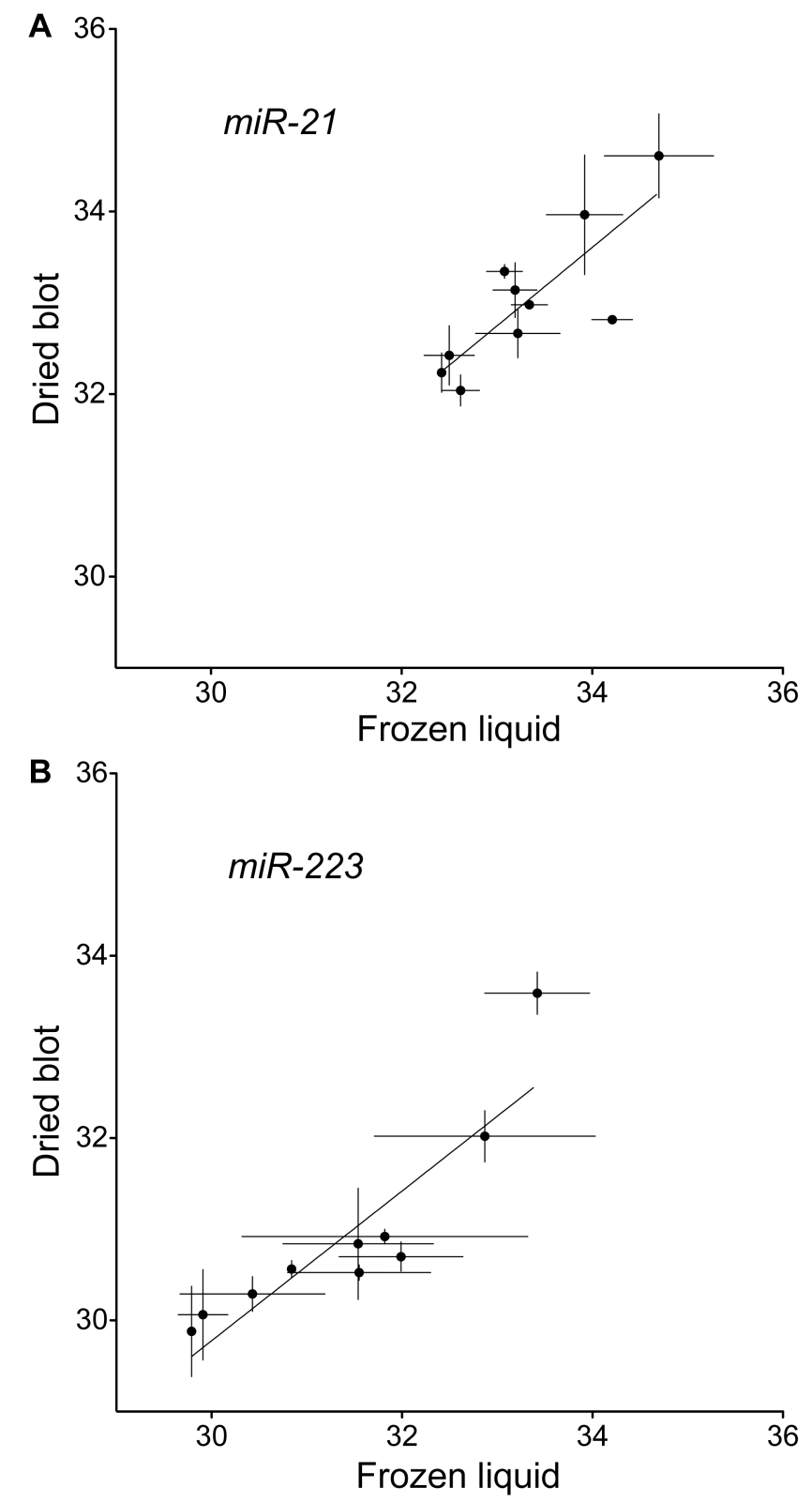


\section{SUPPLEMENTARY DATA}

\section{Figure Legends}

Supplementary figure 1

Effect of the duration of the Trizo/ ${ }^{\mathrm{TM}}$-based re-hydration step on the recovery of microRNAs from dried serum blots. MicroRNA miR-16 was semi-quantified in RNA prepared from identical dried serum blots with a Trizol ${ }^{\mathrm{TM}}$-using re-hydration step of either five or 30 minutes. Mean and range of RT-qPCR $C_{q}$ values for duplicate samples are shown. The t test $P$ value was 0.34 .

\section{Supplementary figure 2}

Equivalence of microRNA preservation in frozen and dried serum over time in a second timeseries experiment. MicroRNA miR-16 was semi-quantified in RNA prepared from serum that was kept frozen at $-80^{\circ} \mathrm{C}$ or dried at room temperature for storage at indicated temperatures for $7,14,21$ or 28 days in a second time-series experiment. Samples from the same timepoint were processed for RT-qPCR together but separately from those from other time-points. Mean and range of RT-qPCR $C_{q}$ values for duplicate samples are shown. Comparisons of the average $C_{q}$ value observed for each sample-type at the four time-points along the time-series using paired t tests showed that the performance of blots over time was not different from that of frozen liquid serum ( $P$ values of $0.69,0.43$ and 0.48 , respectively, for blots stored at -80 ${ }^{\circ} \mathrm{C}$, room temperature, and $37^{\circ} \mathrm{C}$ ). $\mathrm{P}$ values in non-parametric Wilcoxon matched-pairs signed rank tests were $0.88,0.63$ and 0.38 , respectively.

\section{Supplementary figure 3}

MicroRNA miR-16 was semi-quantified in RNA prepared from week-old sera either stored frozen at $-80^{\circ} \mathrm{C}$ or as dried spots prepared at room temperature and stored at $45^{\circ} \mathrm{C}$. Mean and range of RT-qPCR $C_{q}$ values for duplicate samples are shown. The t test $P$ value was 0.10 .

\section{Supplementary figure 4}

Effect of cellulose blot paper on the extractability of microRNAs from liquid sera. MicroRNA miR-16 was semi-quantified in RNA prepared from equal volumes of liquid sera in presence $(+)$ or absence (-) of a blank piece of $1 \mathrm{~cm} \times 1 \mathrm{~cm}$ blot paper. The paper piece was added to sera in a micro-centrifuge tube just before RNA was extracted. Mean and range of RT-qPCR $C_{q}$ values for duplicate samples are shown. The t test $P$ value was 0.30 . 
Supplementary figure 1

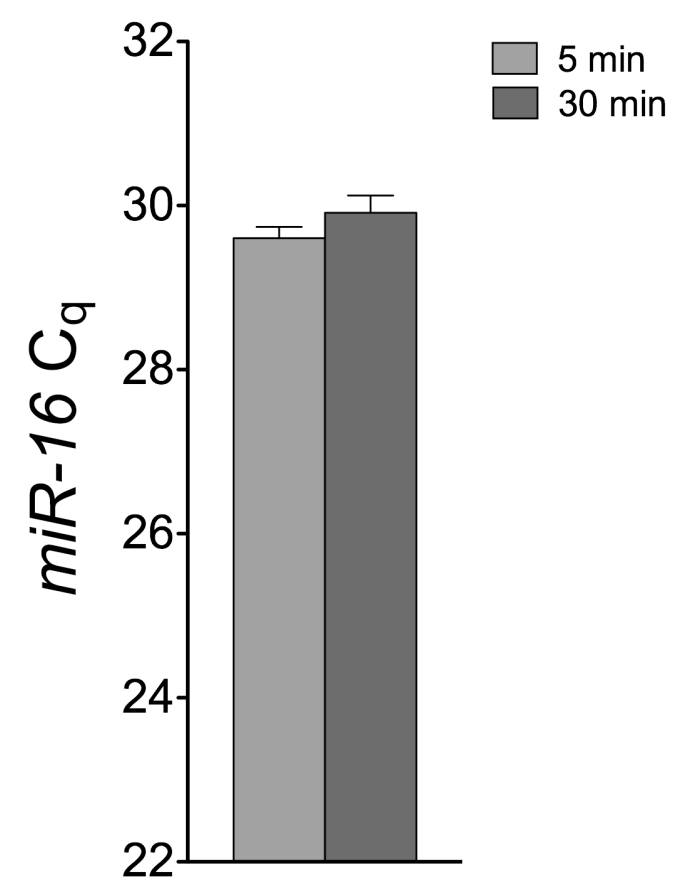


Supplementary figure 2

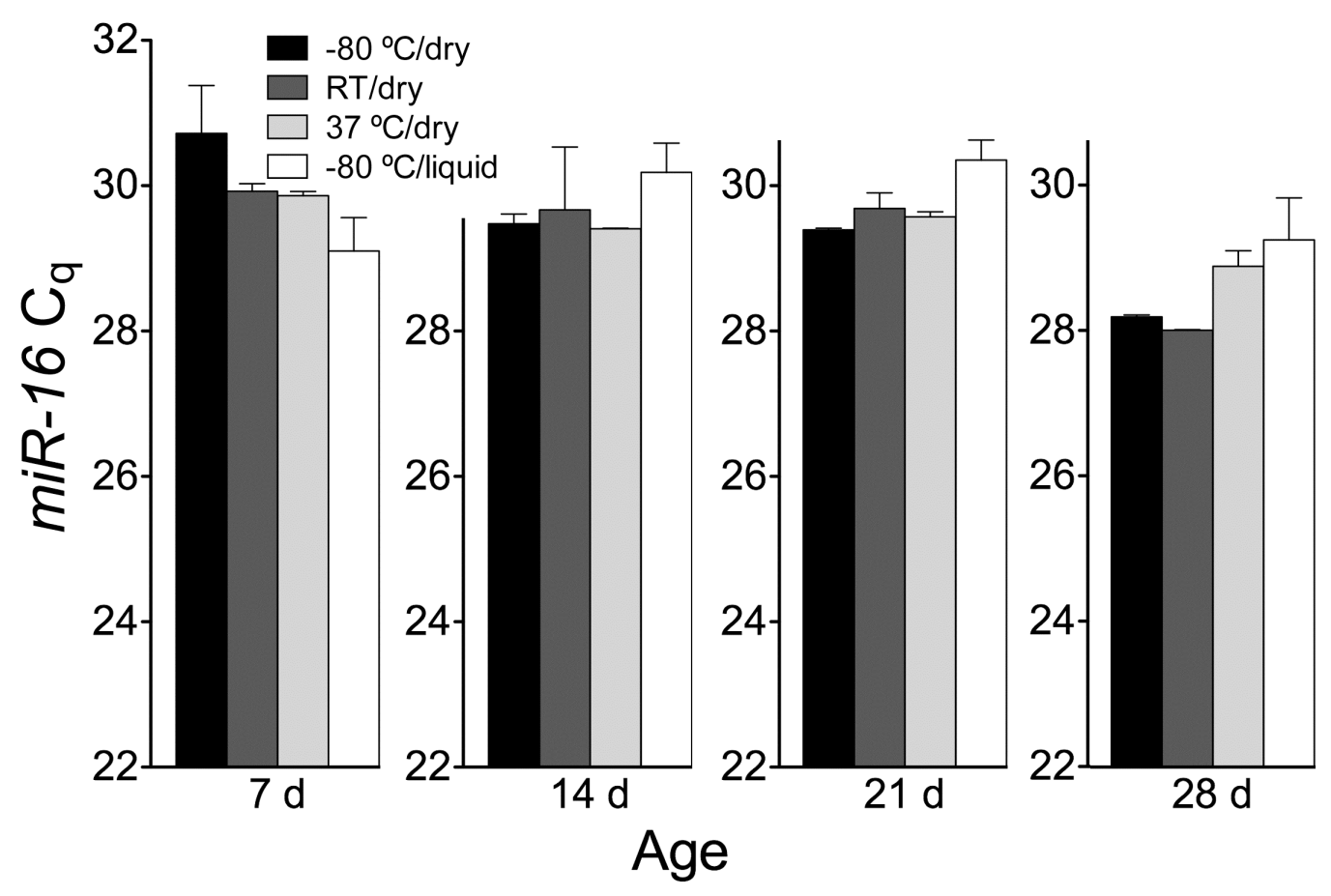


Supplementary figure 3

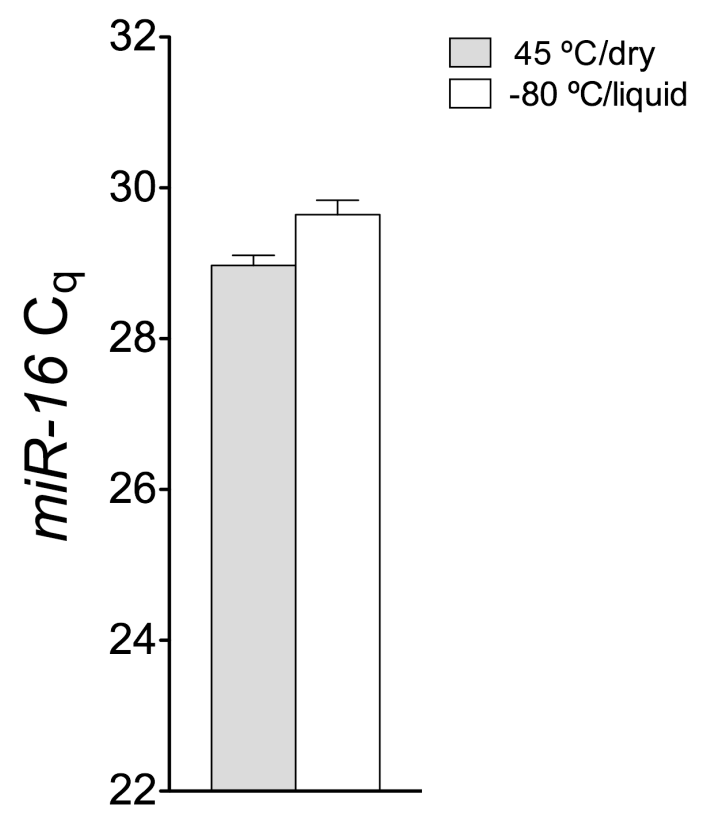


Supplementary figure 4

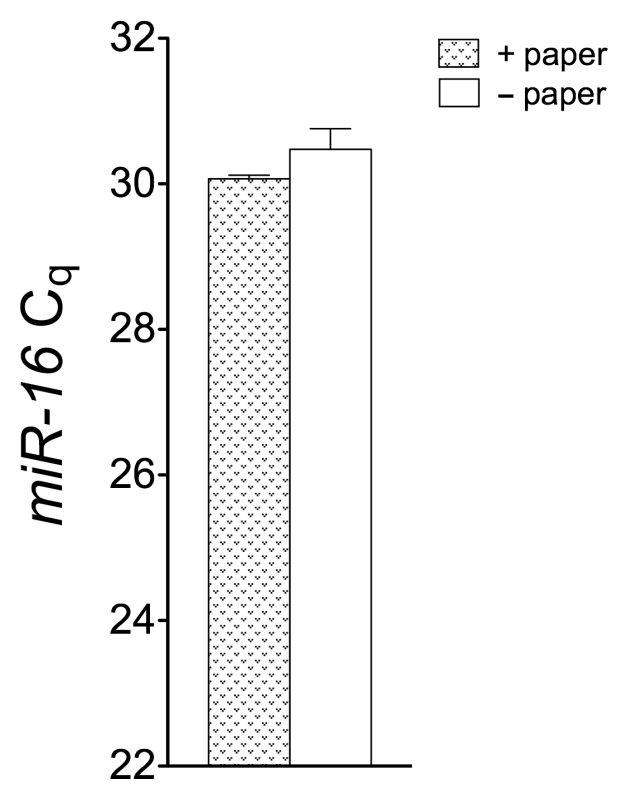

